\title{
Occupational asthma due to methyl methacrylate and cyanoacrylates
}

\author{
S LOZEWICZ, AG DAVISON, A HOPKIRK, PS BURGE, DAR BOLDY, JF RIORDAN, \\ DV McGIVERN, BW PLATTS, D DAVIES, AJ NEWMAN TAYLOR
}

From Brompton Hospital and Central Middlesex Hospital, London; King Edward VII Hospital, Midhurst; East Birmingham Hospital and Dudley Road Hospital, Birmingham; and City Hospital and the Employment Medical Advisory Service, Nottingham

ABSTRACT Five patients had asthma provoked by cyanoacrylates and one by methyl methacrylate, possibly because of the development of a specific hypersensivity response. Acrylates have wide domestic as well as industrial uses, and inhalation of vapour emitted during their use can cause asthma.

Acrylates are widely used in the manufacture of adhesives, solvents, acrylic resins, and thermoplastics. Cyanoacrylate based glues give a high bond strength between a variety of materials and are available for domestic use as Superglue and for surgical use as tissue adhesives. ${ }^{1}$ Methacrylates, which are chemically distinct from cyanoacrylates, serve as bases for acrylic resins, which have various applications, including use as adhesives and fillers in dental and orthopaedic procedures. ${ }^{23}$ Workers in pathology laboratories may be exposed as a result of their use in the plastic embedding of histological specimens.

Low molecular weight acrylic monomers are irritant to the eyes and mucous membranes, and have been reported to produce dermatitis ${ }^{4}$ and pulmonary oedema, ${ }^{5}$ but there is no previous report of an association with asthma. We report five cases of asthma occurring in association with exposure to cyanoacrylate based adhesives, and one case occurring in relation to exposure to methyl methacrylate. In each case, inhalation testing that mimicked exposure at work $^{6}$ provoked an asthmatic reaction.

\section{Methods}

In patients 2 and 3 histamine reactivity was measured by a modification of the method of de Vries.? Histamine acid phosphate solution was delivered from a Wright nebuliser with an oxygen flow rate of 8 litres per minute. The aerosol was inhaled via a

Address for reprint requests: Dr AJ Newman Taylor, Brompton Hospital, London SW3 6HP.

face mask with rebreathing bag for $\mathbf{3 0}$ seconds and $\mathrm{FEV}_{1}$ was measured after five minutes. This was repeated with twofold increases in concentration until a $10 \%$ fall in $\mathrm{FEV}_{1}$ occurred or the maximum concentration of $32 \mathrm{mg} / \mathrm{ml}$ of histamine was reached. A fall in $\mathrm{FEV}_{1}$ of $10 \%$ obtained with this method was taken to indicate the presence of bronchial hyperreactivity. In patients 1 and 7 histamine reactivity was measured by the method of Cockcroft et al. ${ }^{8}$

\section{Case reports}

Results of bronchial provocation testing are shown in the table.

\section{PATIENT 1}

A 52 year old man worked in the manufacture of scientific instruments. About one month after starting to use a methyl cyanoacrylate adhesive, he developed work related respiratory symptoms. He stopped using the adhesive at work and 11 weeks later was admitted to hospital for investigation. Skinprick tests with common inhalant allergens gave negative results. No fall in FEV , followed challenge with histamine. Inhalation testing - the patient working with cyanoacrylate glue in the same way as at work for 25 minutes-provoked a $42 \%$ fall in FEV 15 hours after the challenge and symptoms of rhinitis during most of the day (fig 1 ).

\section{PATIENT 2}

A 53 year old woman worked as a solderer in an electronics factory for 10 years before the onset of respiratory symptoms. Two weeks after starting to use an ethyl cyanoacrylate adhesive to assemble 
Results of bronchial provocation

\begin{tabular}{|c|c|c|c|}
\hline $\begin{array}{l}\text { Patient } \\
\text { No }\end{array}$ & $\begin{array}{l}\text { Bronchial } \\
\text { reactivity to } \\
\text { histamine }\end{array}$ & Acrylate & $\begin{array}{l}\text { Asthmatic } \\
\text { reaction to } \\
\text { acrylate }\end{array}$ \\
\hline 1 & Normal & $\begin{array}{l}\text { Methyl } \\
\text { cyanoacrylate }\end{array}$ & Non-immediate \\
\hline 2 & Normal & $\begin{array}{l}\text { Ethyl } \\
\text { cyanoacrylate }\end{array}$ & Non-immediate \\
\hline 3 & Normal & $\begin{array}{l}\text { Alkyl } \\
\text { cyanoacrylate }\end{array}$ & Non-immediate \\
\hline 4 & Not known & $\begin{array}{l}\text { Ethyl } \\
\text { cyanoacrylate }\end{array}$ & Dual \\
\hline 5 & Not known & $\begin{array}{l}\text { Ethyl } \\
\text { cyanoacrylate }\end{array}$ & Dual \\
\hline 6 & Not known & $\begin{array}{l}\text { Methyl } \\
\text { methacrylate }\end{array}$ & Immediate \\
\hline 7 & Normal & $\begin{array}{l}\text { Methyl } \\
\text { methacrylate }\end{array}$ & No reaction \\
\hline
\end{tabular}

components she began to cough and wheeze. During a week away from work these symptoms improved, but on her return they recurred. She left her job and five months later was admitted for investigation. No fall in $F E V_{1}$ followed challenge with histamine. Single blind inhalation testing with cyanoacrylate glue provoked a $21 \%$ fall in FEV, seven hours after the test. FEV returned to prechallenge levels during the following 48 hours. No asthmatic reaction occurred on a separate control day, when there was no exposure to cyanoacrylate glue (table and figure 1). Skinprick test responses were positive for four common inhalant allergens.

\section{PATIENT 3}

A 34 year old woman used cyanoacrylate glue in the assembly of loudspeakers. One month after starting this job she developed difficulty with breathing, which would start four hours after arriving at work. It became progressively worse during the working week, and improved at weekends and during holidays. A humidifier was installed at her place of work and there was symptomatic improvement on days when it was working. Serial recordings of peak expiratory flow rate showed deterioration at work, which was less severe on days when the relative atmospheric humidity was high (fig 2). No fall in $F E V$ followed inhalation of histamine. Single blind inhalation testing mimicking conditions at work was undertaken (table), cyanoacrylate glue being used for $\mathbf{3 0}$ minutes on two separate days: on the first day humidity was $49 \%$ and on the second $66 \%$. Cyanoacrylate exposure provoked a non-immediate fall in $\mathrm{FEV}_{1}$ of $17 \%$ on the low humidity day and of $10 \%$ on the high humidity day. No asthmatic reaction occurred after testing with a non-cyanoacrylate glue on a separate control day. Skinprick responses were positive for three common inhalant allergens.

\section{PATIENT 4}

A 46 year old woman worked in a factory assembling lampshades for four months without developing respiratory symptoms. Three weeks after starting to use an ethyl cyanoacrylate adhesive she developed episodes of cough and shortness of breath. Her cough became continuous and she began to wheeze, particularly at night. One week after she had stopped being exposed at work single blind inhalation testing with cyanoacrylate glue produced symptoms of rhinitis and an immediate fall in peak expiratory flow (PEF) of $21 \%$. This resolved, but there followed a progressive non-immediate fall, reaching a maximum seven hours after the test of $64 \%$ below the pretest value (table). Exposure to a non-cyanoacrylate glue on a control day produced no asthmatic reaction. Skinprick tests with common inhalant allergens gave negative results.

\section{PATIENT 5}

A 24 year old woman worked in the same factory as patient 4. Two weeks after starting to use an ethyl cyanoacrylate adhesive she developed symptoms of rhinitis and also nocturnal cough and wheeze that improved at weekends. She changed her occupation at work to avoid further exposure, and two months
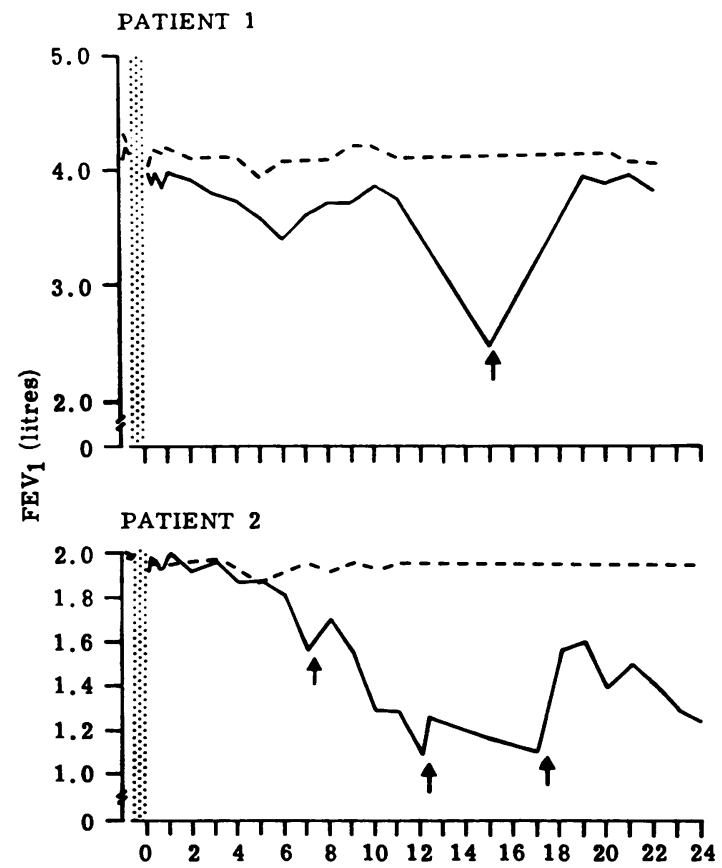

Fig 1 Results of inhalation tests in patients 1 and 2: lung function after exposure to acrylate (see text) (- - ) and on a control day (- -). Treatment with inhaled salbutamol aerosol $200 \mu \mathrm{g}$ is indicated by an arrow. 


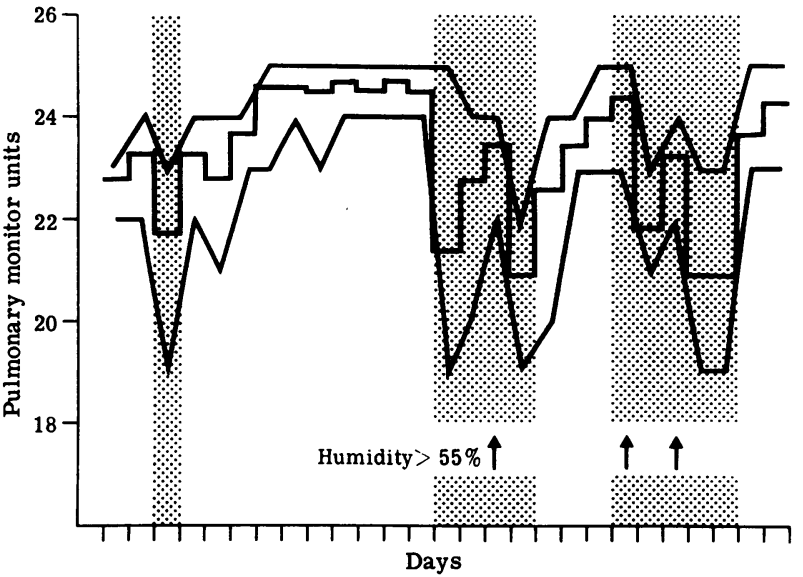

Fig 2 Serial recordings of peak expiratory flow rate (expressed in pulmonary monitor units) in patient 3. The shaded areas indicate periods at work and arrows show the days when a humidifier was in use. later single blind inhalation testing with cyanoacrylate glue provoked an immediate fall in PEF of $28 \%$. This resolved but was followed by a $28 \%$ fall at 8 hours (table). Inhalation testing with a non-cyanoacrylate glue on a separate control day produced no asthmatic reaction. Skinprick tests produced positive responses to four common inhalant allergens.

\section{PATIENT 6}

A 40 year old dental assistant mixed polymethyl methacrylate powder with monomethyl methacrylate liquid to produce a paste used in the manufacture of dental prosthetic trays. After several years of this work he began to experience chest tightness, dyspnoea, and cough, which persisted for several hours after exposure to even small amounts of methyl methacrylate. He gave no history of wheeze or difficulty breathing other than during the episodes at work, and had never been unduly short of breath on exertion. Two weeks after his last exposure at work he underwent inhalation testing in hospital. He mixed methyl methacrylate monomer and polymer, as at work, for 20 minutes. This provoked a fall in PEF of $24 \%$, which resolved over two hours. The test was repeated one week later and provoked a similar immediate asthmatic reaction. No formal control test was made; but serial measurements of peak flow during the week between the two tests varied by less than $10 \%$ around 600 litres per minute, except for a morning dip to 500 litres per minute on waking, which improved spontaneously to 600 litres per minute by 12 midday, the time of the inhalation tests. He has had no recurrence of his asthma during this period.

PATIENT 7

A 52 year old railway cable joiner, who had smoked cigarettes for many years, used an acrylic cold curing resin system containing methyl methacrylate. He developed symptoms of headache, sweating, and lassitude, which occurred in relation to working with the resin system. Although he later developed frequent attacks of cough and wheeze, these respiratory symptoms were not clearly work related. No fall in $\mathrm{FEV}_{1}$ followed inhalation challenge with histamine but serial recordings of peak expiratory flow rate indicated asthma. No asthmatic reaction followed single blind inhalation testing using the resin or control system (table). Skinprick tests with common inhalant allergens gave negative results.

\section{Discussion}

Our findings suggest that in five patients reported here cyanoacrylates are a primary cause of asthma and not acting as a non-specific provocative stimulus in individuals with hyperreactive airways. Each of the five patients who worked with cyanoacrylates had an initial symptom free period of exposure. None of the three tested with histamine showed increased responsiveness before their inhalation tests with cyanoacrylates and these inhalation tests provoked a non-immediate asthmatic reaction in all three. Airway reactivity increases after nonimmediate asthmatic reactions ${ }^{9}$ and decreases with avoidance of exposure to its inducing cause..$^{10}$ Each of these three patients had avoided or reduced their exposure to cyanoacrylates before inhalation testing, which probably explains the absence of increased airway reactivity before the tests. We did not repeat the histamine tests after the inhalation tests with cyanoacrylates, but possibly airway reactivity would have increased after the late asthmatic reactions.

Cyanoacrylate adhesives were introduced for 
commercial use in 1958. "Methyl cyanoacrylate has been most commonly used but more recently ethyl and butyl types have become available. In general, the higher homologues do not have such good bond strength as the methyl homologue but they have the advantage of being less volatile. ${ }^{12}$ Cyanoacrylates readily react with water, polymerising to less volatile polymers. When the relative humidity is high, they react with water vapour in the air and the atmospheric concentration of cyanoacrylate monomer is reduced. Calnan ${ }^{4}$ reported an outbreak of irritant dermatitis associated with the use of ethyl cyanoacrylate glue in electronic assembly workers. This was caused by vaporisation of monomer under conditions of low relative humidity; no further outbreak occurred after the humidity of the working environment had been raised above $55 \%$. Serial recordings of peak expiratory flow rate in patient 3 showed that her asthma was less severe when the atmospheric humidity was relatively high (fig 2 ).

Methyl methacrylate is a clear, flammable liquid that polymerises readily to form non-toxic resins and plastics. It is widely used in surgery as a bone cement and in dentistry as a ceramic filler or cement. ${ }^{23}$ It is also used as a medicinal spray adhesive and a non-irritant bandage solvent. ${ }^{5}$ Threshold limits for methyl methacrylate of $100 \mathrm{ppm}$ have been recommended. ${ }^{13}$ Methyl methacrylate provoked an immediate asthmatic reaction in patient 6 , whose responsiveness to inhaled histamine was not tested and who did not have a control test. We cannot therefore be as confident as with the cyanoacrylates that it was not acting as a non-specific provocative stimulus. This patient had, however, no respiratory symptoms before working with methyl methacrylate, he developed symptoms only after several years of using methyl methacrylate and he has experienced no further symptoms since stopping work with it. Furthermore, inhalation testing in patient 7 , who had asthma, provoked no similar immediate reaction.

Cyanoacrylate and methyl methacrylate monomers can cause asthma in those who work with them. Possibly less volatile, longer chain alkyl cyanoacrylate homologues could be substituted in many adhesives, where the bond strength currently obtained is many times that required. The risk of inhalation of acrylates can be reduced by appropriate ventilation and, in the case of cyanoacrylate monomers, by maintaining relative humidity above $55 \%$.

\section{References}

1 Vaskio JS, Brockman SK. Clinical and experimental experience with plastic adhesives. Ann Surg 1965;162: 123-9.

2 Lee AJ, Wrighton JD. Some properties of polymethylmethacrylate with reference to its use in orthopaedic surgery. Clin Orthop 1973;95:281-7.

3 Gettleman L, Nathanson D, Myerson RL. Porous heat cured poly methylmethacrylate for dental implants. J Biomed Mater Res 1975;9:243-9.

4 Calnan CD. Cyanoacrylate dermatitis. Contact Dermatitis 1979;5:165-7.

5 Sandmeyer EE, Kirwin CJ. Esters. In: Clayton GD, Clayton FE, eds. Patty's Industrial hygiene and toxicology. New York: John Wiley and Sons, 1981:2291-303.

6 Newman Taylor AJ, Davies RJ. Inhalation Challenge Testing. In: Weill H, Turner-Warwick M, eds. Occupational lung diseases. New York: Marcel Dekker, 1980: 143-67.

7 De Vries K. In: Orie NGM, Sluiter HJ, eds. Bronchitis. Assen, Netherlands: Royal Vangorcum, 1960: 221-6.

8 Cockcroft DW, Killian DN, Mellon JJA, Hargreave FE. Bronchial reactivity to inhaled histamine: a method and clinical survey. Clin Allergy 1977; 7:23543.

9 Cartier A, Thomson NC, Frith PA, Tech M, Hargreave FE. Allergen-induced increase in bronchial responsiveness to histamine: relationship to the late asthmatic response and change in airway calibre. $J$ Allergy Clin Immunol 1982;70:170-7.

10 Lam S, Wong R, Yeung M. Non-specific bronchial reactivity in occupational asthma. J Allergy Clin Immunol 1979;63:28-34.

11 Coover HW, McIntire JM. Cyanoacrylate adhesives. In: Skeist I, ed. Handbook of adhesives. New York: Rheinhold, 1977:569-80.

12 Walker RF, Guiver R. Determination of alkyl-2cyanoacrylate concentrations in air. Am Ind Hyg Ass J 1981;42:559-65.

13 Occupational safety and health standards. Subpart Z-Toxic and hazardous substances. Code of Federal Regulations. Title 29, sec. 1910.93. 1976. 